\title{
Comparative effects of 4-Cl-IAA and kinetin on photosynthesis, nitrogen metabolism and yield of black cumin (Nigella sativa $\mathbf{L}$.)
}

\begin{abstract}
SHOUKAT H. SHAH*
Plant Physiology Division, Department of Botany, Aligarh Muslim University, Aligarh 202002, India

The leaves of 40-day old plants of black cumin (Nigella sativa L.) were sprayed with $10^{-7}$, $10^{-6}, 10^{-5} \mathrm{M}$ 4-Cl-IAA, and $10^{-6}, 10^{-5}$ and $10^{-4} \mathrm{M}$ kinetin. Both the hormones improved vegetative growth, photosynthetic efficiency and seed yield of the test plants as compared to deionized water (control). However, $10^{-6} \mathrm{M}$ 4-Cl-IAA was most prominent in its effect, generating 42, 30, 40, 41 and 51\% higher values for carbonic anhydrase, nitrate reductase, net photosynthetic rate, leaf protein content and dry mass respectively, as compared to the control in 70-day old plants. Similarly, capsule number and seed yield per plant were elevated by 41 and $43 \%$ over the untreated control at harvest (130 days after sowing) following the same treatment. Overall, the auxin showed a higher efficiency than kinetin in all treatment concentrations.
\end{abstract}

Key words: 4-Chloroindole-3-acetic acid, photosynthesis, nitrate reductase, carbonic anhydrase, protein, kinetin, yield, Nigella sativa.

Abbreviations; CA - carbonic anhydrase, 4-Cl-IAA - 4-chloroindole-3-acetic acid, NR - nitrate reductase, PAR - photosynthetic active radiation, $\mathbf{P}_{\mathbf{N}^{-}}$net photosynthetic rate, RuBPCO - ribulose-1, 5-bisphosphate carboxylase/oxygenase

\section{Introduction}

Auxins are a class of naturally occurring plant growth substances found throughout the plant kingdom. They are known actively to influence a number of developmental processes such as stem elongation, ethylene biosynthesis and tissue vascularization (NORDSTROM et al. 1991). The first known ubiquitously occurring auxin is indole-3-acetic acid (IAA), but various other analogues such as 4-Cl-IAA have also been identified in certain species. This halogenated compound is characterized by very high auxin-like activity (REINECKE et al. 1995), demonstrated in the growth of excised tissue (KATEKAR and GEISSLER 1982), rooting

\footnotetext{
* Corresponding address, e-mail: shoukathusseine@gmail.com
}

Copyright $^{\circledR} 2011$ by Acta Botanica Croatica, the Faculty of Science, University of Zagreb. All rights reserved. 
in mung bean (STENLID et al. 1987), parthenocarpy and epinasty in tomato (SELL et al. 1953) and the synthesis/induction of specific enzymes in detached pea cotyledons (HIRASAWA 1989, AHMAD and HAYAT 1999, AHMAD et al. 2001a). In addition, acceleration of the rate of photosynthesis resulting in enhancement of the economic yield has also been reported (AHMAD et al. 2001b).

Closely associated in function with auxins are another group of endogenous plant growth substances, the cytokinins. These hormones have an equally potent effect on plant physiology and environmental responses, and are intimately involved in the regulation of cell division, apical dominance, chloroplast development, anthocyanin production and maintenance of the source-sink relationship (HUTCHKINSON and KIEBER 2002). Also, cytokinins are regarded as the most important senescence-retarding hormones and their exogenous application has been demonstrated to prevent the degradation of chlorophyll and photosynthetic proteins (WINGLER et al. 1998), as well as reverse leaf and fruit abscission (PosPíšILOVÁ et al. 2000). Owing to the interlinked nature of the action of these hormones and because of their potential benefits in relation to plant performance and productivity, the present study was designed to compare the effect of auxin (4-Cl-IAA) and cytokinin (kinetin) supplementation on growth, nitrogen metabolism and yield of black cumin (Nigella sativa L.). Though natively Middle Eastern, this herb is valued highly in domestic and international markets owing to its characteristic medicinal and aromatic properties. It is also a significant source of essential fatty acids, carbohydrates, vitamins (A, D, $\mathrm{B}_{2}$ and niacin) and minerals (calcium, potassium, iron, magnesium, selenium and zinc) (SAEED et al. 1996).

\section{Materials and methods}

Seeds of black cumin (Nigella sativa L.) were obtained from the Regional Research Institute of Unani Medicine, Aligarh, and were surface sterilized by soaking in $0.01 \%$ mercuric chloride solution for 3 minutes, followed by repeated washing with double distilled water. The seeds were then sown in earthen pots $(25 \mathrm{~cm}$ diameter $)$, filled with $10 \mathrm{~kg}$ of a mixture of sandy loam soil and farmyard manure in a ratio of 9:1 (w/w). A uniform basal dose $(45,300$ and $78 \mathrm{mg})$ of N, P and K, in the form of urea, single superphosphate and potassium chloride, was applied at the time of sowing to each pot. The pots were lined in the Department's net house, according to simple randomized block design, with three replications. 5 uniform plants were maintained per pot.

4-Chloroindole-3-acetic acid (4-Cl-IAA) and kinetin were obtained from Sigma Chemicals Co., St. Louis, USA. The plants of 40-days age (vegetative stage) were sprayed with $10^{-7}, 10^{-6}$ or $10^{-5} \mathrm{M}$ aqueous solution of 4-Cl-IAA or $10^{-6}, 10^{-5}$ or $10^{-4} \mathrm{M}$ that of kinetin at the rate of $5 \mathrm{~cm}^{3}$ per plant. Control plants were sprayed with double distilled water only. The stage of spraying was determined through an earlier experiment (SHAH 2007).

Five plants from each replicate were randomly selected and carbonic anhydrase activity (CA), dry mass, nitrate reductase activity, net photosynthetic rate $\left(\mathrm{P}_{\mathrm{N}}\right)$, and protein content were assessed at 50 and 70 days after sowing, corresponding to vegetative and flowering stage respectively. The CA activity in the leaves was measured following the procedure described by DWIVEDI and RANDHAWA (1974). Nitrate reductase (NR) activity was determined in fresh leaf samples, followed the method of JAWORSKI (1971). The net photosynthetic rate was measured using a LI-6200 portable photosynthetic system (LI-COR 6200, Lincoln, NE, 
USA) on fully expanded uppermost leaves, at atmospheric conditions (between 1100-1200 h): photosynthetic active radiation (PAR) about $990 \mu \mathrm{mol} \mathrm{m}^{-2} \mathrm{~s}^{-1}$, relative humidity $63 \%$, temperature $23{ }^{\circ} \mathrm{C}$. Protein content of the leaves was estimated by the method of LowRY et al. (1951). Shoot dry mass was determined after dehydrating the plants at $80{ }^{\circ} \mathrm{C}$ for $24 \mathrm{~h}$. Capsule number and seed yield per plant were estimated at harvest (130 days after sowing). Treatment means were compared by analysis of variance using the statistical package SPSS (SPSS 7.5.1 for Windows, standard version 1996). Least significant difference was estimated at 0.05 level of probability.

\section{Results}

Foliar treatment of either hormone was found appreciably to enhance all the studied parameters; however, a higher degree of stimulation was noted following the application of 4-Cl-IAA, especially at the $10^{-6} \mathrm{M}$ concentration. Among different concentrations of kinetin, $10^{-5} \mathrm{M}$ was found to elicit the maximal response (Tabs. 1,2). The activities of enzymes $\mathrm{CA}$ and NR were significantly elevated in the hormone-treated test plants as compared to the water sprayed control. A maximum enhancement of 35 and $42 \%$ was noted in the activity of CA at the 50 and 70 days after sowing sampling stages respectively, following treatment with $10^{-6} \mathrm{M} 4-\mathrm{Cl}$-IAA. On the same sampling days, treatment with kinetin was found to cause an enhancement of 28 and $37 \%$, respectively (Tab. 1). Concurrently, the activity of NR was optimized by 30 and $39 \%$ following the auxin treatment as noted at 50 and 70 days after sowing, respectively. On the other hand, corresponding enhancements of 24 and $32 \%$ in enzyme activity were achieved at the respective samplings from treatment with kinetin. In correspondence with the increase in NR activity, protein content was also found to be enhanced in the leaves of the test plants as compared to the control; there was a maximum enhancement of 27 and $38 \%$ with the auxin treatment in the samplings, respectively. Analogous enhancements of 21 and $29 \%$ were recorded subsequent to treatment with kinetin. $\mathrm{P}_{\mathrm{N}}$ of the treated plants was also appreciably elevated as compared to the control, registering a maximum increase of 26 and $38 \%$ at the 50 and 70 days after sowing stages following 4-Cl-IAA spray. Comparatively, an enhancement of 20 and $30 \%$ was brought about by the kinetin treatment at respective samplings. Consequent to the increased $\mathrm{P}_{\mathrm{N}}$, the test plants also exhibited an increased dry mass production, the maximum enhancement being by 35 and 50\% with 4-Cl-IAA, whereas that with kinetin was 26 and $42 \%$ over the control at respective sampling stages.

Finally, at harvest, the hormone treated plants showed an appreciable improvement of the yield parameters. Number of capsules and seed yield plant ${ }^{-1}$ were increased by 39 and $41 \%$ following the auxin treatment. Correspondingly, treatment with kinetin achieved an increase of 31 and $32 \%$, respectively in the mentioned parameters as compared to the control (Tab. 2).

\section{Discussion}

Test plants receiving either of the hormone treatments exhibited an increase in net photosynthetic rate $\left(\mathrm{P}_{\mathrm{N}}\right)$. This effect could be a consequence of the direct stimulation of the process itself by the hormones, as well as of the optimization of other parameters to facili- 
SHAH S. H.

Tab 1. Carbonic anhydrase (CA) activity $\left[\mathrm{mol}\left(\mathrm{CO}_{2}\right) \mathrm{kg}^{-1} \mathrm{~s}^{-1}\right]$, nitrate reductase (NR) activity [nmol $\left.\left(\mathrm{NO}_{2}\right) \mathrm{g}^{-1} \mathrm{~min}^{-1}\right]$, net photosynthetic rate $\left(\mathrm{P}_{\mathrm{N}}\right)\left[\mu \mathrm{mol}\left(\mathrm{CO}_{2}\right) \mathrm{m}^{-2} \mathrm{~s}^{-1}\right]$, protein content [\% (DM)] and dry mass (DM) $\left[\mathrm{g}\right.$ plant $\left.^{-1}\right]$, in Nigella sativa leaves, sprayed with water (control), 4-Cl-IAA or kinetin (KIN) at 40-d after sowing and sampled at 50 (vegetative stage) and 70 DAS (flowering stage). Each value is mean \pm S.E, $(n=3)$ LSD for $P=0.05$.

\begin{tabular}{|c|c|c|c|c|c|c|}
\hline Parameter & Treatment & {$[\mathbf{M}]$} & 50 DAS & $\begin{array}{l}\% \text { increase } \\
\text { over control }\end{array}$ & 70 DAS & $\begin{array}{l}\text { \% increase } \\
\text { over control }\end{array}$ \\
\hline \multirow[t]{7}{*}{ CA } & control & & $2.17 \pm 0.20$ & - & $2.64 \pm 0.18$ & - \\
\hline & KIN & $10^{-6}$ & $2.51 \pm 0.22$ & 16 & $3.19 \pm 0.23$ & 21 \\
\hline & & $10^{-5}$ & $2.79 \pm 0.17$ & 28 & $3.61 \pm 0.24$ & 37 \\
\hline & & $10^{-4}$ & $2.73 \pm 0.22$ & 26 & $3.56 \pm 0.21$ & 35 \\
\hline & 4-Cl-IAA & $10^{-7}$ & $2.58 \pm 0.15$ & 19 & $3.30 \pm 0.20$ & 25 \\
\hline & & $10^{-6}$ & $2.93 \pm 0.25$ & 35 & $3.74 \pm 0.25$ & 42 \\
\hline & & $10^{-5}$ & $2.88 \pm 0.22$ & 33 & $3.70 \pm 0.23$ & 40 \\
\hline LSD & & & 0.068 & & 0.057 & \\
\hline \multirow[t]{7}{*}{ NR } & control & & $7.11 \pm 0.65$ & - & $7.56 \pm 0.81$ & - \\
\hline & KIN & $10^{-6}$ & $7.97 \pm 0.55$ & 12 & $8.93 \pm 0.54$ & 18 \\
\hline & & $10^{-5}$ & $8.82 \pm 0.65$ & 24 & $9.97 \pm 0.75$ & 32 \\
\hline & & $10^{-4}$ & $8.89 \pm 0.81$ & 25 & $9.90 \pm 0.81$ & 31 \\
\hline & 4-Cl-IAA & $10^{-7}$ & $8.32 \pm 0.64$ & 17 & $9.30 \pm 0.71$ & 23 \\
\hline & & $10^{-6}$ & $9.25 \pm 0.61$ & 30 & $10.50 \pm 0.71$ & 39 \\
\hline & & $10^{-5}$ & $9.17 \pm 0.71$ & 29 & $10.36 \pm 0.81$ & 37 \\
\hline LSD & & & 0.17 & & 0.18 & \\
\hline \multirow{7}{*}{$\mathrm{P}_{\mathrm{N}}$} & control & & $15.01 \pm 1.3$ & - & $16.05 \pm 1.6$ & - \\
\hline & KIN & $10^{-6}$ & $16.66 \pm 1.6$ & 11 & $18.65 \pm 1.9$ & 16 \\
\hline & & $10^{-5}$ & $18.01 \pm 1.7$ & 20 & $20.88 \pm 1.4$ & 30 \\
\hline & & $10^{-4}$ & $17.71 \pm 1.5$ & 18 & $20.38 \pm 1.7$ & 27 \\
\hline & 4-Cl-IAA & $10^{-7}$ & $17.10 \pm 1.6$ & 14 & $19.75 \pm 1.4$ & 23 \\
\hline & & $10^{-6}$ & $18.95 \pm 1.9$ & 26 & $22.15 \pm 1.6$ & 38 \\
\hline & & $10^{-5}$ & $18.61 \pm 1.7$ & 24 & $21.66 \pm 1.7$ & 35 \\
\hline LSD & & & 0.48 & & 0.58 & \\
\hline \multirow[t]{7}{*}{ Protein } & control & & $11.35 \pm 1.1$ & - & $12.75 \pm 1.1$ & \\
\hline & KIN & $10^{-6}$ & $12.83 \pm 1.2$ & 13 & $14.65 \pm 1.4$ & 15 \\
\hline & & $10^{-5}$ & $13.74 \pm 1.4$ & 21 & $16.46 \pm 1.3$ & 29 \\
\hline & & $10^{-4}$ & $13.63 \pm 1.3$ & 20 & $16.34 \pm 1.2$ & 28 \\
\hline & 4-Cl-IAA & $10^{-7}$ & $13.30 \pm 1.5$ & 17 & $15.31 \pm 1.5$ & 20 \\
\hline & & $10^{-6}$ & $14.42 \pm 1.6$ & 27 & $17.62 \pm 1.8$ & 38 \\
\hline & & $10^{-5}$ & $14.21 \pm 1.1$ & 25 & $17.48 \pm 1.5$ & 37 \\
\hline LSD & & & 0.32 & & 0.78 & \\
\hline \multirow[t]{7}{*}{ DM } & control & & $1.15 \pm 0.11$ & & $1.85 \pm 0.17$ & \\
\hline & KIN & $10^{-6}$ & $1.29 \pm 0.12$ & 12 & $2.18 \pm 0.18$ & 18 \\
\hline & & $10^{-5}$ & $1.45 \pm 0.13$ & 26 & $2.63 \pm 0.16$ & 42 \\
\hline & & $10^{-4}$ & $1.44 \pm 0.10$ & 25 & $2.61 \pm 0.19$ & 41 \\
\hline & 4-Cl-IAA & $10^{-7}$ & $1.35 \pm 0.09$ & 17 & $2.31 \pm 0.16$ & 24 \\
\hline & & $10^{-6}$ & $1.55 \pm 0.16$ & 35 & $2.79 \pm 0.20$ & 50 \\
\hline & & $10^{-5}$ & $1.53 \pm 0.15$ & 33 & $2.74 \pm 0.21$ & 48 \\
\hline LSD & & & 0.06 & & 0.08 & \\
\hline
\end{tabular}


Tab 2. Number of capsules and seed yield plant ${ }^{-1}$ in Nigella sativa L. plants, sprayed with water (control), 4-Cl-IAA or kinetin (KIN) at 40-d after sowing and sampled at harvest (130 DAS), LSD for $P=0.05$. Each value is mean \pm S.E, $(n=3)$.

\begin{tabular}{|c|c|c|c|c|c|}
\hline Treatment & {$[\mathbf{M}]$} & $\begin{array}{c}\text { Number of } \\
\text { capsules } \\
{\left[\text { plant }^{-1}\right]}\end{array}$ & $\begin{array}{c}\% \text { increase } \\
\text { over control }\end{array}$ & $\begin{array}{l}\text { Seed yield } \\
{\left[\text { g plant }^{-1}\right]}\end{array}$ & $\begin{array}{l}\% \text { increase } \\
\text { over control }\end{array}$ \\
\hline Control & & $16.15 \pm 1.4$ & - & $1.20 \pm 0.17$ & - \\
\hline \multirow[t]{3}{*}{ KIN } & $10^{-6}$ & $18.50 \pm 1.7$ & 14 & $1.35 \pm 0.20$ & 13 \\
\hline & $10^{-5}$ & $21.28 \pm 1.8$ & 31 & $1.58 \pm 0.21$ & 32 \\
\hline & $10^{-4}$ & $20.98 \pm 1.6$ & 30 & $1.57 \pm 0.19$ & 31 \\
\hline \multirow[t]{3}{*}{ 4-Cl-IAA } & $10^{-7}$ & $19.57 \pm 1.9$ & 21 & $1.43 \pm 0.17$ & 19 \\
\hline & $10^{-6}$ & $22.46 \pm 2.2$ & 39 & $1.69 \pm 0.20$ & 41 \\
\hline & $10^{-5}$ & $22.15 \pm 1.8$ & 37 & $1.65 \pm 0.11$ & 38 \\
\hline LSD & & 0.65 & & 0.05 & \\
\hline
\end{tabular}

tate efficient photosynthetic activity. The elevation of the activities of enzymes CA and NR can be said to have been of significant consequence. After the substrate for carbon fixation, $\mathrm{CO}_{2}$, diffuses into the stomata and is transported into the chloroplast, it is reduced by $\mathrm{RuBPCO}$, the main $\mathrm{C}$ fixing enzyme. However, this supply of $\mathrm{CO}_{2}$ to $\mathrm{RuBPCO}$ depends on the activity of $\mathrm{CA}$, which catalyses the reversible hydration of $\mathrm{HCO}_{3}$ to $\mathrm{CO}_{2}$ in close proximity to RuBPCO. This entire mechanism could have been augmented by the enhancement in CA activity, as achieved in the present study through hormone supplementation. In context of the 4-Cl-IAA treatment, such results can be ascribed to the action of auxins in de-repressing certain genes and in activating the process of translation and transcription (KEY 1969, HopKINS 1995). Similarly, the enhancement effect of kinetin on CA activity can be said to have arisen at the level of transcription and / or stabilization of the transcripts while they increased the content of CA-mRNA through translation (SUGIHARTO et al. 1992). Our hypothesis that enhanced $\mathrm{CA}$ activity brought about an optimization of $\mathrm{CO}_{2}$ availability, consequently to affect $\mathrm{P}_{\mathrm{N}}$, is strongly supported by the positive correlation observed between CA and $\mathrm{P}_{\mathrm{N}}$ of the hormone treated plants $(\mathrm{r}=0.875)$.

Another level of influence for the hormones on $\mathrm{P}_{\mathrm{N}}$ was the protein content in leaves of the test plants, which was enhanced following an increase of NR activity (Tab. 1). NR regulates the major rate limiting stage in the reduction of nitrate to ammonium, which is then incorporated in amino acids (HoPKINS 1995). The hormone treatment resulted in an increase in NR activity and thus elevated the useable form of nitrogen (ammonia) to produce a larger pool of amino acids/amides, in addition to stimulating their incorporation to polypeptide synthesis (by activating transcription and/or translation) and optimizing protein formation. This conjecture is supported by the correlation obtained between NR activity and the level of protein in leaves of the test plants $(r=0.821)$ (SINGH and SINGH 1985). In the context of $\mathrm{NR}$, similar enhancements have been reported following auxin and kinetin treatment, although not from the modulation of the activity of the existing enzyme, but by induction of its de novo synthesis (Premabatidevi 1998). Hence in the present study, the influence of auxins and cytokinins on translation/transcription mechanisms, as aforementioned, can be referred to in the context of increased NR activity and protein content of the test plants. 
In the present study, leaves of plants receiving either of the hormone treatments not only photosynthesized at a faster rate, but also possessed an extended period of metabolic activity, because of the delayed senescence caused by the phytohormones (DAVIES 1995). As a result, these test plants accumulated a large quantity of metabolites, which is evident from the increase observed in their dry mass (Tab. 1). A similar positive relation between $\mathrm{P}_{\mathrm{N}}$ and dry mass production has been observed by KHAN (1994).

The sufficient availability of nutrient facilitated ample vegetative growth in the treated plants, thus resulting in an increase in the number and size of reproductive sink (number of capsules per plant) (Tab. 2). This, when coupled with the 4-Cl-IAA-enhanced mobilization of photoassimilates to the developing capsules (DAVIES 1995), may have further stimulated their growth and hence caused an increase in seed yield, as observed herein (Tab. 2). Likewise, the effect of kinetin on economic yield, though relatively mild, may be ascribed to the increased opportunity for formation of new buds (BRUINSMA 1977), and successful reversal of flower and fruit abscission (NAGEL et al. 2001).

Conclusively, the efficacy of auxin (4-Cl-IAA) was found to be superior to that of kinetin with regard to performance and productivity of Nigella sativa. The relatively subdued effect of kinetin may have been because endogenous cytokinin is seldom limiting in plants, and hence exogenously applied hormone seems less effective (MOORE 1989).

\section{Acknowledgement}

The author wishes to thank the Regional Research Institute of Unani Medicine, Aligarh (UP), India, for gracious provision of Nigella seeds.

\section{References}

Ahmad, A., Hayat, S., 1999: Response of nitrate reductase to substituted indole acetic acids in pea seedlings. In: Srivastava, G.C., Singh, K., PAL, M. (eds), Plant physiology for sustainable agriculture. Pointer Publishers, Jaipur.

Ahmad, A., Hayat, S., Fariduddin, Q., Alvi, S., 2001a: Germination and amylase activity in grains of wheat, treated with chloroindole acetic acids. Seed Technology 23, 88-91.

Ahmad, A., Hayat S., Fariduddin Q., Ahmad, I., 2001b: Photosynthetic efficiency of plants of Brassica juncea, treated with chlorosubstituted auxins. Photosynthetica 39, $565-568$.

Bruinsma, J., 1977: Rolle der Cytokinine bei Bluten-und Fruchteentwicklung. Zeitschrift für Pflanzenernährung und Bodenkunde 140, 15-23.

DAVIES, P. J., 1995: The plant hormones: their nature, occurrence and functions. In: DAVIES, P.J. (ed), Plant hormones, physiology, biochemistry and molecular biology, 1-12. Kluwer Academic Publishers, Dordrecht.

DwIVEDI, R. S., RANDHAWA, N. S., 1974: Evaluation of rapid test for hidden hunger of zinc in plants. Plant Soil 40, 445-451. HiRASAWA, E., 1989: Auxin induces a-amylase activity in pea cotyledons. Plant Physiology 91, 484-486.

HopkIns, W. G., 1995: Plants and nitrogen. In: HopkINS, W. G (ed.), Introduction to plant physiology, 118. John Willey and Sons, New York. 
Hutchkinson, C. E., KieBer, J. J., 2002: Cytokinin signaling in Arabidopsis. Plant Cell 14, $547-559$.

JAWORSKI, E. G., 1971: Nitrate reductase assay in intact plant tissue. Biochemical and Biophysical Research Communications 43, 1274-1279.

KATEKAR, G. F., Geissler, A. E., 1982: Auxin II. The effect of chlorinated indoleacetic acids on pea stems. Phytochemistry 21, 257-260.

KEY, J. L., 1969: Hormones and nucleic acid metabolism. Annual Review of Plant Physiology and Molecular Biology 20, 449-474

KHAN, N. A., 1994: Variation in carbonic anhydrase activity and its relationship with photosynthesis and dry mass of mustard. Photosynthetica 30, 317-320.

Lowry, O. H., Rosebrough, N. J., FArR, A. L., Randall, R. J., 1951: Protein measurement with Folin - Phenol reagent. Journal of Biological Chemistry 193, 265-275.

Moore, T. C., 1989: Biochemistry and physiology of plants hormones. Springer Verlag, New York.

Nagel, L., Brewster, R., Reidell, W. E. Reese, R. N., 2001: Cytokinin regulation of flower and pod set in soybeans (Glycine max L.). Annals of Botany 88, 27-31.

Nordstrom, A., Jacobs, F. A., Fliasson, L., 1991: Effect of exogenous indole-3-acetic acid and indole-3-butyric acid on internal levels of the respective auxins and their conjugation with aspartic acid during adventitious root formation in pea cuttings. Plant Physiology 96, 856-861.

Pospíšilová, J., Synková, H., Rulcová, J., 2000: Cytokinins and water stress. Biologia Plantarum 43, 321-328.

PREMABATIDEVI, R. K. 1998: Effect of IAA, GA 3 and kinetin on nitrate reductase and nitrite reductase in the leaves of a tree legume. Indian Journal of Plant Physiology 397-101.

Reinecke, D. M., Ozga, J. A., Magnus, V., 1995: Effect of halogen substitution of indole-3-acetic acid on biological activity in pea fruit. Phytochemistry 40, 1361-1366.

Saeed, A., Rizvi, M. A. Ahmad, L., 1996: Cultivation of medicinal herbs at Madinat Al-Hikmah. Hamdard Medicus 39, 23-26.

Sell, H. M., Witter, S. H., Rebstock, T. L. Redemann, C. T. 1953: Comparative stimulation of parthenocarpy in the tomato by various indole compounds. Plant Physiology 28, 481-487.

SHAH, S. H. 2007: Effect of kinetin spray on growth and productivity of black cumin plants. Russian Journal of Plant Physiology 54, 702-705.

SinGH, V. P., SINGH, M., 1985: Nitrate reductase activity and its relationship with grain protein and grain yield of wheat. Indian Journal of Plant Physiology 28, 235-242.

STENLID, G., ENGVILD, K. C., 1987: Effects of chloro substituted indole acetic acids on root growth, ethylene and ATP formation. Physiologia Plantarum 70, 109-113.

Sugiharto, B., SugiYama, T., 1992: Effects of nitrate and ammonium on gene expression of phosphoenolpyruvate carboxylase and nitrogen metabolism in maize leaf tissue during recovery from nitrogen stress. Plant Physiology 98, 1403-1408.

Wingler, A., Von Schaewen, A., Leegood, R. C., LeA, P. J., Quick W. P. 1998: Regulation of leaf senescence by cytokinin, sugar, and light. Plant Physiology 116, 329-335. 